\title{
Transportation of Goods Responsibility in Sea Transportation Based on Law Number 17 Of 2008 Concerning Shipping
}

\author{
Rineke Sara \\ Dosen Fakultas Hukum Universitas Boroudur Jakarta, \\ Jl. Raya Kalimalang No.1, Cipinang Melayu - Jakarta Timur \\ \{rineke_sara@borobudur.ac.id\}
}

\begin{abstract}
With the increasing and rapid movement of production, transportation problems are very important in various aspects of life. Indonesia is an archipelagic country, it is necessary to ships as a means of transporting goods to deliver goods needed by the people from one island to another. In this case the carrier must be responsible for and obliged to maintain the safety and security of the goods transported from the moment of receiving the goods until they are delivered or received. The sender is obliged to pay the fare according to the contract that has been made. In connection with the issue of responsibility, the carrier is obliged to pay compensation for damage or loss of the goods carried. Therefore, legal protection is needed for the sender or receiver of goods to protect their rights and obligations, as regulated in Law Number 17 of 2008 concerning Shipping. Responsibility for goods transported by the transportation company in accordance with the rights paid by service users as regulated in Law Number 8 of 1999 concerning Consumer Protection. Settlement of loss of goods is only unilaterally determined by the transportation company which only pays attention to the initial agreement regardless of the compensation mechanism.
\end{abstract}

Keywords: Responsibility; Compensation for Sea Transportation

\section{Introduction}

Transportation is one of the most important activities, due to Indonesia's geography which consists of large, small islands and is surrounded by oceans. So that the distribution of goods and the mobility of people from one place to another can be carried out by transportation by land, sea and air to all regions in Indonesia. Initially, transportation as a means of transporter in the agreement was only verbal. However, in its development, it must be made in writing and also supported by transportation documents.

As stated by R. Subekti; The law of transportation is part of (company) trade law and (company) trade law, including in the field of civil law. In terms of normative legal structure, the field of civil law is the sub-system of the national legal system. Thus, commercial law (company) is included in the sub-system of national legal order. The principles of the national legal order are also the principles of the law of transportation. 
On the other side R. Soekardono also said that; "Transportation basically contains the movement of places both regarding objects and about people, because this movement is absolutely necessary to achieve and increase benefits and efficiency."

Basically, transportation has the purpose of moving goods or people from one place to another with the aim of increasing utility and value. So that through transportation, goods can be transferred from one place where the goods are deemed less useful to the place where the goods are felt to be more useful. The transfer of goods or people from one place to another by means of transportation must be carried out in compliance with several conditions which cannot be abandoned, that it must be carried out safely, safely, quickly, without changing the form of the place and time.

All losses incurred on the ship are the responsibility of the ship operator (carrier), except if the loss arises due to force majeure (overmacht, force majeure) that occurs not because of the carrier error, which cannot be known or can not be predicted will occur when making the agreement, defects in the goods themselves, where the defective goods are not due to the fault of the crew during the transportation process, and errors or negligence of the sender, such as incomplete packing so as to facilitate the entry of sea water. Prior to the commencement of the goods delivery process, the stakeholders should committed themselves to an agreement, especially shippers / owner of the goods and the freight / cargo company.

Soetjipto Rahardjo, also stated that; "Legal protection is an effort to protect someone's interest by allocating a power to him to act in his interest. Furthermore, it is also stated that one of the characteristics and at the same time is the goal of law is to provide protection (protection) to the community."

The legal protection of society must be realized in the form of legal certainty because the number of users haulage transport services either land, sea or air which causes problems caused by multiple factors. This can be seen in several cases such as the case of PT Arpeni Pratama Ocean Line Tbk. with PT Trans Lintas Segara and PT Exploitasi Energi Indonesia Tbk, for the negligence of Defendant I, therefore, PT Expl exploitation Energi Indonesia Tbk. cannot be said to have non-performance of contract. As well as case of PT. Wawasan Kebun Nusantara with PT BONA Trans Persada, PT Alzano Surya Kencana Nusantara, PT Pelayaran Nasional Lautan Kumala, Kesyahbandaran Utama Pelabuhan Belawan, PT Asuransi Tokio Marine Indonesia and PT Lintas Kumala Abadi. Where the Defendant 1 replaced the transport ship that was originally promised to use KM Samudro Endah but in fact used the KM Kumala Endah belonging to PT Pelayaran Nasional Lautan Kumala without notification to the Plaintiff and the the approval of the Plaintiff. 


\section{Main Issue}

a. How is the responsibility of the carrier in sea transportation based on Law No. 17 of 2008 concerning Shipping?

b. What is the responsibility of the carrier for the destruction of goods in sea transportation?

\section{Methodology}

This research is a juridical nomative research, where the study is legal principles, legal synchronization, legal comparisons, and history consisting of primary legal materials and secondary legal materials. The data were obtained through literature study and documents and analyzed inductively qualitatively to get a conclusion.

\section{Literature}

\subsection{Agreement}

\subsubsection{Definition of Agreement}

An agreement is a legal event that often occurs in social life. One of the sources of the agreement is the law, the source of both parties, which fulfills the requirements as determined by law. Rudi Prasetya said, "An agreement is an consent between two or more parties to do something or not to do something reciprocally. Article 1313 of the Civil Code, explains that, "An act by which one or more people bind himself to one or more other people".

In connection with this, it is necessary to improve the definition where actions must be interpreted as legal actions, namely actions that aim to cause legal consequences and add the words "or mutually bind themselves" in Article 1313 of the Civil Code. So that the formulation becomes: A contract is a legal act in which one or more people bind themselves or bind themselves to one or more people.

Sutojo also explain that:; "An agreement is a legal relationship between two or more people to cause permissible legal consequences. The agreement is made by at least two people, where each as the first party and the second party, the party that is obliged to fulfill something is the debtor (the party owing it) and the party entitled to fulfill something is called the creditor (the party owed)".

The agreement also called for the approval of the parties that promised it agrees to do something. An agreement that is born because of the agreement is what the parties who make the agreement want. If two or more parties have agreed to make an agreement, the parties intend to bind themselves in a legal relationship and are bound to each other because of the promises they have given and of course they must fulfill what they have promised. It can be concluded that an agreement is a legal act between two or more people who bind themselves to each other based on an agreement to cause legal consequences.

An agreement valid if it has met the conditions determined as stipulated in Article 1320 of the Civil Code, which is agreement for those who bind themselves, the ability to make an engagement, a certain matter and a lawful cause.

\subsubsection{Covenant Principles}


The agreement gives the widest possible freedom for people to make it and can contain anything on the condition that it does not violate public order and morals. In addition, in making an agreement several important principles can be found, as for these principles:

a. The principle of freedom of contract, this principle is a form of free will of humans or society, this is related to the time the agreement was made or in other words related to the contents of the agreement. The parties can set aside articles containing the agreement which are complementary to the law if the parties making the agreement wish..

b. The principle of consensualism, the principle is an agreement born at the moment an agreement is reached, meaning that there is an agreement with the will of the parties making the agreement. In other words, the agreement already exists and is valid, binding, if an agreement has been reached between two or more people who promise each other, basic matters without any need for formalities unless the law stipulates otherwise..

c. The principle of Pacta Sunt Servanda, this principle is in accordance with the provisions of Article 1338 paragraph (1) of the Civil Code which reads, All agreements made legally apply as law for those who make them. Legal certainty will be seen from the strength of the binding of the agreement, as law for the parties who made it.

d. Good faith principle, this principle is in accordance with the provisions of Article 1338 paragraph (3) of the Civil Code states, an agreement must be carried out in good faith. Good faith determines what the agreement actually contains and does not change the agreement. This relates to the interpretation of the meaning of an agreement, namely seeking the intentions of the parties, either those stated clearly in the agreement or those implied by the agreement.

e. Personality Principle, this principle explains that basically an agreement does not create rights or obligations for third parties. The agreement only binds the parties so that it does not cause loss or gain for the third parties. This can be concluded from Articles 1315 and 1340 of the Civil Code.

\subsection{Transport Agreement}

\subsubsection{Definition of Transport Agreement}

Transportation is a business activity in the field of transportation services using mechanical transportation means. Mechanical transporters, for example, are carriages to transport goods, trains to transport passengers, trucks to transport goods, buses to transport passengers, cargo planes to transport goods, passenger planes to transport passengers, cargo ships to transport goods. Transportation as a process in application has system elements, there are;

a. The subject (actor) of Transportation is the parties in transportation and parties with an interest in transportation.

b. The status of the transporter, especially the transporter, always has the status of an individual company, an association, a legal entity.

c. The status of the transporter, especially the transporter, always has the status of an individual company, an association, a legal entity.

d. A transportation event is the process of transporting and carrying out transportation and ending at the destination.

e. The transportation relationship is the relationship of obligations and rights between the parties in transportation and those with an interest in transportation.

A transportation agreement is an agreement in which one party undertakes to safely carry 
people or goods from one place to another, while the other party agrees to pay the cost. The carrier must carry out the transportation process safely, either carrying people or goods. Safely means to always take good care of the goods so that the goods are always in a safe condition in accordance with the conditions since they were received. Meanwhile, the other party is obliged to pay shipping costs to the carrier.

The Law of Carriage provides that transportation is only held or carried out after transportation costs have been paid in advance. Then the custom also applies to the community who can pay transportation costs later. The transportation agreement usually includes transportation activities in a broad sense, namely the activities of loading, carrying, and unloading / unloading, unless another agreement is stipulated in the agreement. Also includes the responsibility of the carrier in the event of an event that causes loss. In other words, the responsibility of the carrier starts from the time the passenger and / or goods are loaded into the carrier until the passenger is unloaded from the carrier or the goods are unloaded from the carrier or handed over to the person receiving the goods..

\subsubsection{Law of Transportation Principles}

The principle of transportation law is a philosophical basis that can be divided into two, there are the principle of public law and the principle of civil law

\section{a) Principles of Public Law}

1. The principle of benefit, implies that every transportation must be able to provide maximum use value for humanity, increase people's welfare, and develop a balanced life for Indonesian citizens..

2. The principle of collective effort and familial, meaning that the transport business is held to realize the ideals and aspirations of the people of Indonesia in its activities can be carried out by the whole society and imbued with the spirit of brotherhood.

3. The principle of fairness and equality, implies that transportation administration must be able to provide fair and equitable services to all levels of society, at a cost that is affordable to the community..

4. The principle of balance, implies that the operation of transportation must be in a harmonious balance between facilities and infrastructure, between the interests of users and service providers, between individual and community interests, and between national and international interests.

5. The principle of public interest implies that transportation operations must prioritize the interests of public services for the wider community.

6. The principle of integrity, implies that transportation must be a whole and unified unity, integrated, mutually supporting and complementary, both intra and between modes of transportation.

7. The principle of legal awareness implies that the government is obliged to uphold and guarantee legal certainty and oblige every Indonesian citizen to always be aware and obey the law in the implementation of transportation.

8. The principle of self-confidence implies that transportation must be based on belief in one's own ability and strength as well as based on the national personality.

9. The principle of passenger safety implies that the transportation of passengers must be accompanied by accident insurance and / or other loss insurance. Passenger safety is not only left to insurance protection, but also the operator of the transportation company 
must endeavor to provide and maintain transportation equipment that meets safety standards in accordance with the provisions of international laws and conventions.

\section{b) Principles of Civil Law}

1. The agreement principle implies that every transportation is made by agreement between the carrier and the owner of the goods. The carriage agreement is not required to be in writing, it is sufficient with the agreement of the parties. However, to certify that the agreement has occurred and is binding, it must be proven with or supported by transport documents.

2. The principle of coordination implies that the parties in transport have an equal or equal position, no party overcomes or supervises other parties. Although the transporter provides services and carries out orders from the owner of the goods, the transporter is not subordinate to the owner of the goods.

3. The principle of mix, means that transportation is a mixture of three types of agreement,there are granting power of attorney, storing goods, and carrying out work from passengers or goods owners to the carrier, unless otherwise stipulated in the agreement.

4. The principle of retention implies that the carrier does not use the right of retention (right to hold goods). The use of retention rights is against the purpose and function of carriage. Transport only has the obligation to store goods at the owner's expense.

5. The principle of proof by document implies that every transportation is always proven by transportation documents. No document of transport means no agreement of carriage, unless there are generally accepted customs, for example, transportation with an urban carrier (angkot) without a passenger ticket / ticket.

\section{c) The Parties to the Law of Transport}

The parties to the law of transportation are called the parties to the transportation agreement, including the carrier, sender, forwarder, travel agent, loading and unloading company, warehouse company and receiver.

1. Carrier, is a party that binds itself to carry out the transportation of goods and / or passengers. Those may have the status of State-Owned Enterprises, Private-Owned Enterprises, or individuals operating in the field of transportation services, which have the characteristics and characteristics of a carrier, include, among others, a transportation organizing company, using mechanical transportation means and issuing transportation documents.

2. Shipper (Consigner, Shipper), is the party who reminds himself of the transportation agreement to be able to pay the cost of transportation for the goods being transported. Senders who do not collect their goods from the designated storage area within a stipulated time will be charged a storage fee for the goods.

3. Expeditor is a person / legal entity whose job is to find carriers of goods on land or in waters for the benefit of the sender. The expeditor is an entrepreneur who runs a company in the freight forwarding business, such as railroad cargo expedition, ship cargo expedition and aircraft cargo expedition.

4. Travel Agent, is a party that finds passengers for the carrier, acts on behalf of the carrier and provides transportation facilities to passengers by selling tickets / tickets to 
passengers and the passenger pays transportation costs which are then deposited by the travel agent to the carrier and the travel agent. get provisions from the carrier.

5. Stevedoring Company, is a company that runs a business in the field of loading and unloading goods from ships. This company is a company that stands alone or can also be part of a carrier company. If the loading and unloading company is part of a transport company, from a legal perspective of transportation, the act of loading and unloading is an act of the carrier in carrying out transportation and all illegal acts committed by loading and unloading entrepreneurs and their workers are the responsibility of the carrier..

6. Warehousing company is a company engaged in the business of storing goods in a port warehouse as long as the goods are waiting for loading onto the ship or waiting for release from the port warehouse which is under the supervision of the Customs and Excise Service. There are three kinds of warehouses, there are:

a. Free warehouse is a warehouse for storing / hoarding goods that is free from all obligations and inspections from the Customs and Excise Service.

b. An entrepot warehouse is a warehouse for storing / hoarding goods whose status and destination are not yet known and is under the supervision of the Customs and Excise Service because the importer's obligations are not fulfilled.

c. Customs warehouse is a warehouse for storing / hoarding goods that have just been unloaded from the ship or which will soon be loaded onto the ship.

7. The recipient (Consignee), is the sender who can be known from the transportation documents, can be a buyer / importer or a party obtaining the power of attorney or sender. With the characteristics and characteristics of the recipient, including but not limited to companies or individuals obtaining rights from the sender of the goods, evidenced by mastery of transportation documents and paying or without paying transportation costs.

\subsection{Sea Freight}

\subsubsection{Definition of Sea Freight}

Transportation is a transportation activity in moving goods and passengers from one place to another or it can be said as an expeditionary activity. Some definitions of transportation according to experts, including Nurcahyo Purwosutjipto, said that; "Transportation is a reciprocal agreement between the carrier and the sender, in which the carrier binds himself to carry out the transportation of goods and / or people from one place to a certain destination safely, while the sender binds himself to pay the transportation money.".

Ridwan Soekardono, also said that; "Transportation contains the movement of places both regarding objects and regarding people, because this movement is absolutely necessary to achieve and increase benefits and efficiency. The process of transportation is a movement from the place of origin from which the transportation activity starts to the destination where the transportation ends.".

Furthermore, based on the provisions in Article 1 number 2 and number 3 of Law Number 17 of 2008 concerning Shipping, hereinafter referred to as the Shipping Law states that; "Indonesian water are the territorial sea of Indonesia and its archipelagic also inland waters. Transportation in waters is an activity to transport and / or move passengers and / or goods by boat".

Based on the operational definition of Article 1 point 2 and point 3, what is meant by the 
definition of sea transportation which is used in the term water transportation, is the activity of transporting and / or moving passengers and / or goods by ship. Meanwhile, what is meant by waters, namely Indonesian waters is the Indonesian territorial sea along with its archipelagic and inland waters. While the means of transportation are ships. In addition to the meaning of transportation in waters, there are also important terms in sea transportation, there are:

a. Sea Transportation is a transportation activity which according to its activities serves sea transportation activities.

b. River and Lake Transportation is a transportation activity that includes reservoirs, swamps, riverbanks, canals.

c. Cross Transportation is transportation that functions as a movable bridge that connects road networks and / or rail networks that are cut off due to water.

As a service activity in moving goods or passengers from one place to another, sea transportation plays an important role in creating a dynamic national distribution pattern. The practice of operating a sea transportation can provide the greatest use value in the world of trade. And in its implementation it should be carried out fairly and evenly to all levels of society and prioritizing the interests of public services with a view to increasing the utility and value for the benefit of society

\subsubsection{Types of Sea Transportation}

According to the provisions of Law Number 17 of 2008 concerning Shipping Article 1 points 4, 5, 8 and 10, it is stated that the types of sea transportation in Indonesia. The types in question are; Point 4; Special Sea Transportation is a transportation activity to serve its own business interests in supporting its main business. Point 5; People-Sailing Sea Transportation is a people's business that is traditional in nature and has its own characteristics to carry out transportation in the waters using sailing ships, motorized sailing ships, and / or simple motorboats with Indonesian flags with certain sizes.

Point 8; Pioneer Voyages are transportation services in the waters on routes determined by the Government to serve areas or areas that have not been or are not served by water transportation because they have not provided commercial benefits. Point 10; Multimodal transportation is the transportation of goods using at least 2 (two) different modes of transportation on the basis of 1 (one) contract that uses multimodal transportation documents from one place where goods are received by the multimodal transport operator to a place determined for delivery of said goods..

Furthermore, according to the provisions of Article 7 of Law No.17 of 2008 concerning Shipping, the types of sea transportation are domestic sea transportation, foreign sea transportation, special sea transportation, and public shipping sea transportation.”.

a. Domestic Sea Transportation is sea transportation activity carried out in Indonesian territorial waters which is carried out by the national sea transportation company or in the sense that it is carried out by using the boundaries of domestic sovereignty. Domestic shipping which includes:

1. Nusantara Shipping, which is a voyage to carry out the business of transportation between Indonesian ports regardless of the direction taken from one another in accordance with the applicable regulations Its shipping radius is more than 200 nautical miles.

2. Local Shipping, is shipping to carry out the business of transportation between Indonesian ports aimed at supporting domestic shipping and overseas shipping by using ships with a gross size of $500 \mathrm{~m} 3$ or less or equal to $175 \mathrm{BRT}$ and below. The 
radius of voyage is less than 200 nautical miles or equal to 200 nautical miles.

3. People's voyage, is shipping the archipelago using sailboats.

b. Foreign Sea Transportation, is the activity of sea transportation from a special port or terminal open to foreign trade to foreign ports or from foreign ports to Indonesian special ports or terminals open to foreign trade organized by sea transportation companies or in the sense that carried out by transporting in the free oceans connecting one country to another. Overseas shipping, which includes:

1. Near Ocean Shipping, is shipping to the ports of neighboring countries that do not exceed a distance of 3,000 nautical miles from the outer ports of Indonesia, regardless of the direction;

2. Ocean voyages is voyages to and from abroad that are not near ocean voyages.

c. Special Sea Transportation, is a transportation activity to serve its own business interests in supporting its main business.

d. People's Sailing Sea Transportation, is a people's business that is traditional in nature and has its own characteristics to carry out transportation in the waters using sailing ships, motorized sailing ships, and / or simple motorboats with Indonesian flags with certain sizes.

\subsubsection{Parties to Sea Freight}

Parties to the law of sea transportation are legal subjects. The legal subjects of transportation can have the status of legal entities, non-legal associations, and individuals. The legal subjects of transportation are supporters of rights and obligations in the legal relationship of transportation, namely the parties to the transportation agreement, there are:

a. Carrier, is a party that binds itself to carry out the transportation of goods and / or passengers. Can have the status of a State-Owned Enterprise, Private Owned Company, or an individual who operates in the transportation service sector.

b. Shipper (Consigner, Shipper), is the party who reminds himself of the transportation agreement to be able to pay the cost of transportation for the goods being transported. Senders who do not collect their goods from the designated storage area within a stipulated time will be charged a storage fee for the goods. If there is a delay in departure by the carrier, the carrier is obliged to pay compensation in the amount of transportation costs that have been paid by the sender.

c. Expeditor is a person / legal entity whose job is to find carriers of goods on land or in waters for the benefit of the sender. An expeditor is an entrepreneur who runs a company in the freight forwarding business, such as railroad cargo expedition, ship cargo expedition and aircraft cargo expedition. The forwarder takes care of various kinds of documents and formalities that apply in order to enter and / or remove goods from the transportation means or warehouse at the station / port / airport.

d. Travel Agent, is a party that searches passengers for carriers. This travel agent acts on behalf of the carrier and provides transportation facilities to passengers by selling tickets / tickets to passengers and the passenger pays transportation costs which are then deposited by the travel agent to the carrier and the travel agent gets a provision from the carrier.

e. Stevedoring Company, is a company that runs a business in the field of loading and unloading goods from ships. This company is a company that stands alone or can also be part of a carrier company.

f. Warehousing company is a company engaged in the business of storing goods in a port 
warehouse as long as the goods are waiting for loading onto the ship or waiting for release from the port warehouse which is under the supervision of the Customs and Excise Agency. There are three types of warehouses, namely:

a. Free warehouse is a warehouse for storing / hoarding freight that is free from all obligations and inspections from the Customs and Excise Agency.

b. Entrepot is a warehouse for storing / hoarding goods whose status and destination are not yet known and is under the supervision of the Customs and Excise Agency because the importer's obligations are not fulfilled.

c. Bounded warehouse is a warehouse for storing / hoarding goods that have just been unloaded from the ship or which will soon be loaded onto the ship.

g. The recipient (Consignee), is the sender who can be seen from the shipping documents. It may be a buyer / importer or party who obtains power of attorney or sender.

\subsubsection{Rights and Obligations in Sea Transportation}

Provisions of Law No. 17 Year 2008 about Shipping, Article 38, Article 40 and Article 41 as follows: Article 38

a. Transport companies in sea transport are obliged to carry passengers and / or goods, especially postal transportation as agreed in the transportation agreement.

b. The transportation agreement as referred to in paragraph (1) is proven by passenger tickets and cargo documents.

c. In certain circumstances, Government mobilizes the commercial fleet national.

This provision is intended so that transport companies do not discriminate users of their transport services as long as they have fulfilled the transportation agreement. Provisions of Article 40 states;

a. Sea transport companies are responsible for the safety and passengers and / or the goods security.

b. Sea transport companies are responsible for the cargo according to the type and quantity stated in the cargo document and / or the agreement or contract of transportation that has been agreed.

Article 41 also states that;

a. Responsibility as referred in Article 40 may arise as a result of operating a ship, in the form of: death or injury of the passengers being transported; destroyed, lost, or damaged goods transported; delay in the transportation of passengers and / or goods being transported; loss of third parties.

b. If the losses as referred to in paragraph (1) letter b, letter c, and letter $d$ are proven to be not caused by their mistake, the sea transport company can be partially or completely released from the responsibilities.

c. Sea transport companies are required to insure their responsibilities as referred in paragraph (1) and carry out basic protection insurance for public passengers in accordance with the provisions of laws and regulations.

Those article explained that death or injury of passenger being transported, is the death or injury of the passenger caused by an accident during transportation and occurring on the ship, and / or accidents while getting on or off the ship, in accordance with legislation. This responsibility is in accordance with the transportation agreement and regulations. It includes providing services to passengers within eligibility boundary while waiting for departure, for example a delay in departure due to negligence of the sea transport company. Meanwile, letter $\mathrm{d}$ that meant by "third party" is an individual Indonesian citizen or a legal entity that has 
nothing to do with the ship operation, but affected by death or loss or damaged caused by ship operation.

Government Regulation No. 20/2010 about Sea Transport, Article 177 states;

a. Sea transportation companies i are obliged to carry passengers and / or goods, especially postal transportation as agreed in the transportation agreement.

b. The transportation agreement as referred to in paragraph (1) shall be proven by a passenger ticket or document payload.

c. Before carrying out the transportation as referred to in paragraph (1), the sea transport company must ensure.

d. Ship transport facilities have met the requirements of marine feasibility.

e. Ship transport facilities have been filled with sufficient fuel, fresh water and are equipped with logistical supplies.

f. Passenger room, cargo storage, cold storage, and other storage places on the ship are sufficient and safe for passengers and / or loaded goods.

g. The way of loading, handling, storing, stacking and unloading goods and / or getting on or off passengers is done thoughfully and carefully.

Furthermore, according to Article 180, it also explains that;

1. Sea transport companies are responsible for the safety and safety of passengers and / or the goods they transport.

2. The sea transport company is responsible for the cargo of the ship according to the type and quantity stated in the cargo document and / or the agreement or contract of transportation that has been agreed.

Basically, transport obligation includes responsibility to transport the goods of the senders safely to their destination. After transport agreement is approved, the carrier has the right to receive fees / wages / shipping costs paid by the sender. Payment can be made directly when the goods are sent or when the goods are received, this is based on the transport agreement itself. Then, after the sender has an obligation to pay the fee, the sender has the right to receive the goods whether it is received by a third party, namely the recipient or the sender himself . Then the transporter's obligation is to transport the goods from the place of departure to the agreed destination safely. In return, The carrier is entitled to receive an amount of service fee or rent which is called transportation fee. The sender's obligation is to pay an amount of money as transportation costs and obtain the right to transport it to its destination safely.

\section{Study Result}

5.1 Responsibility of Sea Transport Carriage Based on Law Number 17 Of 2008 Concerning Water-Borne Shipping

Basically, the obligation of transportation includes the responsibility of the carrier to transport goods belonging to the sender safely to their destination, after the agreement of carriage is approved. The carrier is entitled to receive fees / wages / shipping costs paid by the sender. Where the carrier obligation is to transport goods from the place of departure to the agreed destination safely. The main obligation of the carrier is to carry out transportation from the place of origin to the place of destination. Transportation also has the right to maintain the safety of the goods it transports until reaches the destination as being agreed. On the other hand, the transporter is also entitled to the transportation costs that he organizes.

In principle, responsibilities can be distinguished as follows: 
a. Responsibility for errors, here the carrier is responsible for the losses suffered by the sender of the goods because the goods are lost, damaged, or destroyed due to the operation of the transport. This responsibility starts from the time the goods are received by the carrier until the delivery of the goods to the recipient.

b. Responsibility due to presumption, where the carrier is always considered to be responsible for any losses arising from the shipping, but if the carrier can prove that they are innocent, then he is freed from the responsibility to pay compensation for the damages. Not guilty means not having done negligence, having tried to take the necessary actions to avoid losses, or events that caused the loss could not be avoided.

c. Absolute responsibility, in this case the carrier must be responsible in principle for any losses incurred in transportation, without having to prove whether there is an error on the part of the carrier. This principle recognizes no burden of proof and the element of error does not need to be questioned. The carrier cannot be free from responsibility for any reason that gives rise to the loss.

Thus, it is clear that to distinguish the principle of responsibility it is put on the issue of proof, whether or not there is an obligation of proof, and to whom the burden of proof is borne in the prosecution process. Furthermore, as stipulated in Article 1365 of the Indonesian Civil Code (KUHPerdata), every act violating the law, which brings harm to other people, obliges the person because of his wrongdoing to issue the loss, to compensate the loss. So transportation can also be demanded for compensation for damaged goods unless there are four things that must be considered as meant in Article 91 Indonesian Commercial Law Code (KUHD):

a. The state of forcing or overmacht, Articles 91, 92 and 93 KUHD, basically the carrier or the shipping companies and even the owner of the ship must be responsible for all goods that have been agreed for transport. This responsibility is waived if the cause of damage to the goods is caused by the goods themselves, or by circumstances outside their control that cause the goods to not arrive at their destination as intende. The state of force or overmacht / force majeure is one of the clauses that are usually used in an agreement, because its position in an agreement is a principal agreement, it is not separated as an additional agreement and is linked to the main agreement as an accessoir agreement. Specific article about forcing condition or overmacht/force majeure arranged in KUHPerdata is only related to compensation costs and .

b. About defective goods itself, Article 93 of the KUHD states that after payment of the wages for the transportation of commodity and goods that have been transported on the basis of the order is received, all rights to claim damages to the carrier or ship's owner will be annulled. time can be seen from the outside. Also refers to the provisions of Article 1366 of the Civil Code, that everyone is responsible, not only for losses caused by their actions, but also for losses caused by negligence or carelessness, goods that were flawless and then handed over defective or damaged, the carrier is not can be categorized as free from legal responsibility.

c. The sender's error can legally be linked to Article 1366 of the KUHPerdata, which explains that everyone is responsible, not only for the losses caused by their actions, but also for the mistakes of the sender. For example, he is not honest about the quality of goods or hidden or invisible defects to explain to the party who will transport the goods. In the agreement for the delivery of the goods, the obligations of each agreement should be based on the principle of good faith, in accordance with the provisions of Article 1338 of the KUHPerdata. 
d. Goods that late to arrive due to damage, as the provisions of Article 1367 of the KUHPerdata, where a person is not only responsible for losses caused by his / her own actions, but also for losses caused by the actions of those who are dependent on them, or due to goods under supervision.

Thus, it is clear that the sea transport company which is responsible for the safety and security of the passengers and / or the goods being transported is also responsible for the cargo of the ship according to the type and quantity stated in the cargo document and / or the agreement or transport contract that has been agreed upon, as stated described in Article 40 of Law Number 17 of 2008 about Shipping. When relating with Law Number 8 of 1999 concerning Consumer Protection Article 19, it explains that:

a. Business actors are responsible for providing compensation for damage, pollution, and / or loss to consumers due to consuming goods and or services produced or traded.

b. (2) The compensation as referred to in paragraph (1) can be in the form of refunding money or replacing goods and / or services of similar or equivalent value, or health care and / or provision of compensation in accordance with the provisions of the prevailing laws and regulations.

c. The compensation is given within a grace period of 7 (seven) days after the transaction date.

d. The provision of compensation as referred to in paragraph (1) and paragraph (2) does not eliminate the possibility of a criminal charge based on further evidence regarding the element of error.

In the case of transportation of goods and / or persons, the legal relationship between the carrier and the user of the transportation service has been regulated and legal certainty is guaranteed in the statutory regulations and its implementation is carried out through an agreement. In connection with the difference in position between business actors and consumers where business actors generally have a stronger position compared to the position of weak consumers, it is necessary to protect consumers. The position of consumers in conducting legal relations with business actors has the principle that business actors who have a contractual relationship with consumers are obliged to protect consumers.

\subsection{Responsibility of the Carrier for the Destruction of Goods in Sea Transportation}

The provisions of Articles 1365 and 1367 of the Civil Code. Article 1365 of the Civil Code, that for every act against the law which causes harm to another person, obliges the person who because of his actions caused the loss to compensate for the loss, so that person must be responsible for paying compensation suffered. Whereas Article 1364 of the Civil Code requires the fulfillment of four main elements of an illegal act, namely the existence of an act, an element of error, the existence of a loss suffered and the existence of a causal relationship between error and loss. Whereas Article 470 of the KUHD also regulates exemptions, and states that the carrier has the authority to require that he will not be responsible for not more than a certain amount for each item transported.

The carrier is responsible for losses suffered by the sender of the goods due to lost, damaged, or destroyed goods caused by the operation of the transport. This responsibility starts from the time the goods are received by the carrier until the delivery of the goods to the recipient. Losses are calculated based on the actual losses experienced, excluding profits earned and service fees that have been used. However, the Carrier is not responsible for losses caused by incorrect information in the letter of transport of goods.

Where the burden of proof is on the carrier, not on the party who is injured. The party that 
has suffered losses is sufficient to show that there is a loss suffered in transportation carried out by the carrier. Where the principle of absolute responsibility, the carrier must be responsible for any losses incurred in the transportation carried out without having to prove whether or not there was an error in the carrier. This principle recognizes no burden of proof and the element of error does not need to be questioned. The carrier cannot be free from responsibility for any reason that gives rise to the loss. The way to distinguish the principles of responsibility is basically laid on the problem of proof, namely whether there is an obligation of proof, and to whom the burden of proof is borne in the prosecution process.

According to Article 1366 of the Civil Code, "every person is responsible not only for losses caused by his actions, but also for losses caused by negligence or carelessness". then each carrier is obliged to be responsible for any losses caused by his actions as well as negligence or carelessness.

\section{Conclusion and Recommendation}

\subsection{Conclusion}

Based on the research results, it can be concluded that the following are::

a. The carrier responsibility in general is based on responsibility due to error, responsibility because of presumption, absolute responsibility. Besides that, a person is not only responsible for losses caused by his own actions, but also for losses caused by the actions of his dependents, or due to goods under his supervision as stipulated in Article 1367 of the Civil Code and Article 91 of the Civil Code, as well as the provisions of Articles 40 to 43 of Law no. 17 of 2008 concerning Shipping. Where the debtor can be sued to pay fees, losses and interest (compensation), if he deliberately does not fulfill the achievement or neglects to do so.

b. The transporter's responsibility for the destruction of goods during sea transportation, is the obligation of the agreed legal actions as referred to in Article 1320 and Article 1338 of the Civil Code. The responsibility of the goods transported by the transportation company according to the rights paid by the sea transportation company service user, it is the obligation that the goods must arrive at their destination. As is also protected by Law Number 8 of 1999 concerning Consumer Protection. If the goods sent by users of the transportation service do not arrive at their destination or are lost or damaged, then the transportation company must be legally responsible for all the risks, because this can be categorized as an illegal act.

\subsection{Recommendation}

As a suggestion to anticipate problems in the responsibility of transporters in sea transportation, in order to ensure justice for parties who have been harmed by legal actions committed by the carrier, it is necessary to provide an explanation from the parties responsible for the existence of legal certainty.

\section{References}


[1] Rudi Prasetya, Aspek Perjanjian Menurut Hukum Perdata, Jakarta: Jambatan, 2011, hal. 47

[2] Kitab Undang-Undang Hukum Perdata (KUHPerdata), Pasal 1313

[3] Sutojo, Asas-asas Hukum Perjanjian, Jakarta: Grafindo Jaya, 2001, hal. 19

[4] KUHPerdata, Op.cit, Pasal 1320

[5] Abdulkadir Muhammad, Hukum Pengangkutan, Darat, Laut, dan Udara. Bandung; Citra Aditya Bhakti, 1994, hal 21

[6] Abdulkadir Muhammad, Hukum Pengangkutan Niaga, hal 52-55

[7] Nurcahyo Purwosutjipto, Pengantar Hukum Tranportasi, Jakarta; Gramedia, 2014, hal 109

[8] Ridwan Soekardono, Hukum Dagang Indonesia, Jakarta; Grafitty Press, 2016, hal 63

[9] UU No. 17 Tahun 2008, Op.cit, Pasal 1 angka 2 dan 3

[10] Ridwan Soekardono, Op.cit, hal 87

[11] UU No. 17 Tahun 2008, Op.cit, Pasal 1 angka 4, 5, 8 dan 10

[12] Ibid, Pasal 7

[13] Ibid, Article 38

[14] Ibid, Article 40

[15] Ibid, Article 41

[16] Government Regulation No. 20 of 2010 concerning Transportation in Waters, Article 177

[17] Ibid, Article 180 